\author{
(online) $=$ ISSN $2285-3642$ \\ ISSN-L = $2285-3642$ \\ Journal of Economic Development, Environment and People \\ Volume 10, Issue 4, 2021 \\ URL: http://jedep.spiruharet.ro \\ e-mail: office jedep@spiruharet.ro
}

\title{
Vertical Integration in Agro-Industry: Eco-Friendly Gambier Products
}

\author{
Hamira ${ }^{1}$, Bernadette Robiani ${ }^{1}$ and Mukhlis ${ }^{1}$ 目 \\ ${ }^{1}$ Faculty of Economics, Sriwijaya University
}

\begin{abstract}
Textile dyeing on fabrics and clothing causes environmental pollution and health problems. There is an innovation of natural coloring using gambier in the Gambo Muba fabric industry and the garment industry in Indonesia. Gambier farmers supply natural dye raw materials. Then through the supply chain of the Gambo Muba fabric industry and the garment industry, it causes vertical integration in the gambier agro-industry. This study uses primary data from 39 vertically integrated companies in the gambier agroindustry, including the gambier rubber industry, the Gambo Muba fabric industry, and the garment industry. The data was then analyzed using descriptive qualitative. This study analyzes the relationship between vertically integrated industries, including the transaction costs between them, their impact of vertical integration on added value, and their profitability. Vertically integrated industries have low transaction costs. The impact of vertical integration on the gambier agro-industry adds to the chain of economic activities that can increase added value and profits. The impact of vertical integration can reduce transaction costs, especially the supplier coordination cost component, distributor cost component, intercompany lobbying costs components. The benefits of vertical integration in the gambier agro-industry are increasing high added value, profit levels, decreasing environmental pollution, and agro-industry sustainability.
\end{abstract}

Keywords: Vertical integration, added value, profit

JEL Codes: L22; L11; L10; Q12; Q13

How to cite: Hamira, H., Robiani, B., \& Mukhlis, M. (2021). VERTICAL INTEGRATION in AGRO-INDUSTRY: ECO-FRIENDLY GAMBIER PRODUCTS. Journal of Economic Development, Environment and People, 10(4), 9-

17. doi:http://dx.doi.org/10.26458/iedep.v10i4.711

\section{Introduction}

The use of textile dyes in the clothing industry can cause significant soil pollution levels in the long term [1] [2]. Textile dyeing waste is not very environmentally friendly and very dangerous [3]. The process of making clothes not only causes soil pollution but also causes water and air pollution. The manufacturing process involves consuming large amounts of water, energy, and various chemicals that produce waste. Waste is not reprocessed and immediately being thrown away, causing environmental damage such as gas emissions, odors, and water pollution [4] [5] [6] [7]. Harmful dyes or chemical dyes release toxic gases into the environment, causing safety and health problems for humans and animals [8] [9], causing severe skin problems such as irritation and allergies, digestive problems, and sometimes even cancer [10]. There are more than 1,900 chemicals used in clothing production, of which the EU classifies 165 of them as

Corresponding author: hamira834@gmail.com 


\author{
(online) $=$ ISSN $2285-3642$ \\ ISSN-L = $2285-3642$ \\ Journal of Economic Development, Environment and People \\ Volume 10, Issue 4, 2021 \\ URL: http://jedep.spiruharet.ro \\ e-mail: office jedep@spiruharet.ro
}

hazardous to health or the environment [11]. From an environmental perspective, replacing synthetic dyes with natural dyes is a strategy to reduce pollutants and a new market and job opportunity [12].

The global issue related to the apparel or garment industry is that this industry is a pollutant industry that affects global environmental pollution. Both production and processing of raw materials are contributing factors to pollution [13]. To reduce this pollutant problem, the garment industry chooses materials to the dyes eco-friendly and begins to pay attention to the dyes used. Indonesia needs environmentally friendly natural dyeing alternatives. Thus, natural coloring innovations have begun, especially gambier coloring. Gambier is a kind of sap derived from extracts of leaves and twigs of the gambier plant. Gambier can be used for natural dyes for environmentally friendly textile products [14].

The Gambier plantation produces gambier sap and has also been developed into a traditional fabric dye (which is named Gambo Muba jumputan cloth) in Musi Banyuasin district, Indonesia. The production of gambier plants produces dry gambier sap and liquid gambier sap. The use of liquid gambier for fabric dyes replaces textile dyes, where fabric dyes from gambier adhere firmly to fabric fibers, do not fade, are environmentally friendly, and do not cause skin cancer. Natural dyes from gambier are an alternative to imported synthetic dyes, producing reddish-brown, dark brown, black, green, or light brown colors if added with color-generating substances. Interestingly, gambier can be an alternative for natural dyes on fabrics and clothing with economic value, is environmentally friendly, and is safe for health. The relationship between the output of gambier sap which is used as an input for natural dyes in the fabric industry and the output of cloth used as input in the garment industry allows for vertical integration in the gambier agro-industry.

\title{
2. Analysis of Recent Research and Publications
}

Vertical integration is a company strategy that controls raw materials from the upstream supply chain and downstream supply chain. Vertically integrated industries have raw material availability and control over the entire supply chain [15] [16] [17] [18]. Industries that perform vertical integration are not only to maintain their product chains but to achieve economies of scale and profitability [19] [20] [21]. Research [22] and [23] found a correlation between vertical integration and agro-industry performance [18] asserted that vertically integrated agro-industry has the advantage of monitoring product quality and quantity throughout the supply chain. In addition, vertical integration is also associated with transaction costs in industry coordination [24] [25].

Vertical integration describes the extent to which the company controls the production of inputs and distribution of outputs or finished products Vertical integration of agricultural products means that all activities from farming to processing are carried out by an entrepreneur or processing factory to increase added value. The factor that drives companies to do vertical integration is the flexibility of operations [27]. Internal vertical integration is a structural response to industry and market characteristics as a way for companies to compete effectively [28]. Vertical integration should be considered from two points of view, namely internal benefits and costs and effects on competitive posture. Internal benefits affect the strategy's profitability, and strength in competitive posture allows the firm to be more responsive to changing market needs and move away from competitors [29].

The advantages of vertical integration are that companies can lower their transaction costs, vertically integrated companies can ensure stable inputs, correct market failures due to externalities by internalizing these externalities, companies can avoid government regulations, restrictions, and taxes, and create market power [30] [27]. 


\author{
(online) = ISSN $2285-3642$ \\ ISSN-L = 2285 - 3642 \\ Journal of Economic Development, Environment and People \\ Volume 10, Issue 4, 2021 \\ URL: http://jedep.spiruharet.ro \\ e-mail: office jedep@spiruharet.ro
}

Transaction costs in vertical integration are costs incurred by companies to carry out strategies to maintain an efficient supply chain. Transaction costs consist of supplier coordination costs, labor organization costs, managing distributor costs, commission, and fees [31].

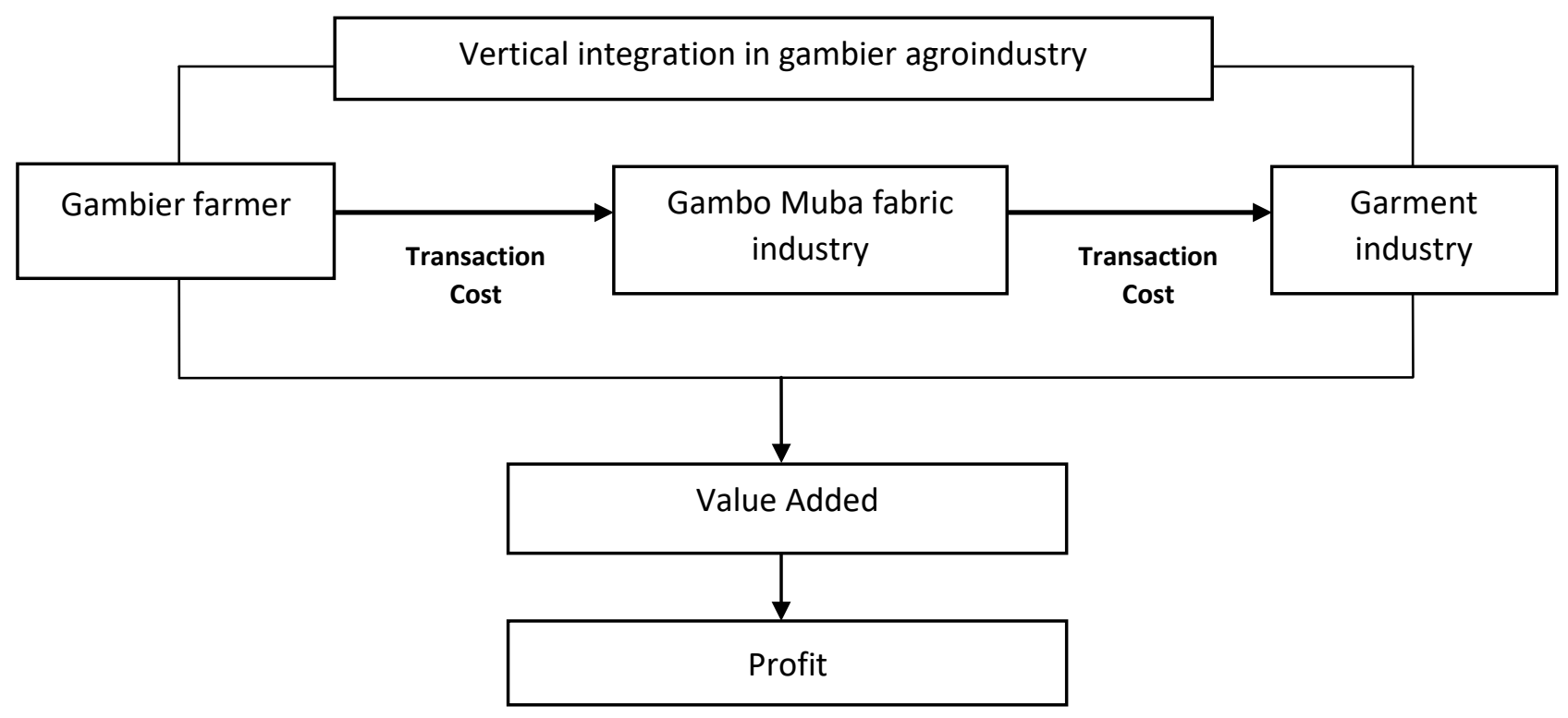

Figure 1. Conceptual Framework

Vertical integration explains the existence of input-output linkages in the gambier agro-industry in Musi Banyuasin Regency, Indonesia. The output of gambier sap is the input for the Gambo Muba fabric industry. Then the output in the Gambo Muba fabric industry becomes the production input for the garment industry. The analysis of vertical integration of gambier agro-industry can be seen from the analysis of transaction costs. Transaction costs in vertical integration are costs incurred by companies to carry out strategies to maintain supply chains. Transaction costs consist of supplier coordination costs, labor organization costs, managing distributor costs, commission fees, and other fees. These costs are costs that arise when an exchange occurs. The behavior of vertical integration determines the performance of the gambier agro-industry, including added value and profit level.

\title{
3. Research Methods
}

This study analyzes vertical integration and its relationship to added value and profits in the gambier agroindustry. The gambier agro-industry in question is an industry with supply chain linkages to gambier agricultural products, including the gambier sap farming business, the Gambo Muba fabric industry using dyes from gambier sap, and the garment using the raw material for the Gambo Muba fabric industry. A total of 39 companies were selected using the side proportional random technique [32]. This research was conducted in Musi Banyuasin Regency in South Sumatra Province, Indonesia. The data used are primary data from the Gambier agro-industry that implements a vertical integration strategy. 


\author{
(online) $=$ ISSN $2285-3642$ \\ ISSN-L = 2285 - 3642 \\ Journal of Economic Development, Environment and People \\ Volume 10, Issue 4, 2021 \\ URL: http://jedep.spiruharet.ro \\ e-mail: office jedep@spiruharet.ro
}

\title{
4. Results
}

The overall description of the variables is shown in Table 1 . The value of minimum, maximum, mean, and standard deviation will be analyzed empirically.

Table 1. Descriptive Statistics

\begin{tabular}{|l|r|r|r|r|r|r|}
\hline Variable & \multicolumn{1}{|c|}{$\mathrm{N}$} & \multicolumn{1}{c|}{ Minimum } & \multicolumn{1}{c|}{ Maximum } & \multicolumn{1}{c|}{ Sum } & \multicolumn{1}{c|}{ Mean } & Std. Deviation \\
\hline $\begin{array}{l}\text { Total Production } \\
\text { Input (IDR) }\end{array}$ & 39 & $2,718,833$ & $37,070,813$ & $572,820,197$ & $14,687,697$ & $9,178,244$ \\
\hline $\begin{array}{l}\text { Total Production } \\
\text { Output (IDR) }\end{array}$ & 39 & $4,200,000$ & $59,400,000$ & $888,565,000$ & $22,783,718$ & $14,635,048$ \\
\hline $\begin{array}{l}\text { Transaction Cost } \\
\text { (IDR) }\end{array}$ & 39 & 52,000 & 398,000 & $6,951,500$ & 178,244 & 102,742 \\
\hline $\begin{array}{l}\text { Value Added } \\
\text { (IDR) }\end{array}$ & 39 & $2,297,500$ & $33,034,834$ & $561,088,666$ & $14,386,889$ & $9,333,753$ \\
\hline $\begin{array}{l}\text { Price-Cost Margin } \\
\text { (\%) }\end{array}$ & 39 & 7.04 & 64.70 & $1,483.69$ & 38.04 & 17.10 \\
\hline
\end{tabular}

Source: Proceed Data, 2021

There is a product differentiation strategy undertaken by the company to differentiate products offered in the market. The differentiation of gambier products is shown in Table 2.

Table 2. Descriptive of Gambier Product Differentiation

\begin{tabular}{|c|c|c|}
\hline Product & Frequency & Percentage of \\
\hline \multicolumn{3}{|c|}{ Agricultural Products } \\
\hline Liquid gambier sap & 7 & 53.85 \\
\hline Solid gambier sap & 6 & 46.15 \\
\hline Total & 13 & 100.00 \\
\hline \multicolumn{3}{|c|}{ Products of Gambo Muba } \\
\hline Fabrics Gambo Muba fabrics silk & 2 & 15.38 \\
\hline Gambo Muba viscose fabric & 5 & 38.46 \\
\hline Gambo Muba cotton rayon & 6 & 46.15 \\
\hline Total & 13 & 100.00 \\
\hline \multicolumn{3}{|c|}{ Garment Products } \\
\hline Shirt & 7 & 53.85 \\
\hline Blouse & 2 & 15.38 \\
\hline Dress & 3 & 23.08 \\
\hline Bomber jacket & 1 & 7.69 \\
\hline Total & 13 & 100.00 \\
\hline
\end{tabular}

Source: Proceed Data, 2021 


\author{
(online) $=$ ISSN $2285-3642$ \\ ISSN-L = $2285-3642$ \\ Journal of Economic Development, Environment and People \\ Volume 10, Issue 4, 2021 \\ URL: http://jedep.spiruharet.ro \\ e-mail: office jedep@spiruharet.ro
}

There are two types of gambier agricultural products, namely liquid and solid gambier sap products. Liquid gambier sap products are used for dyeing traditional fabrics in the Gambo Muba fabric industry, including Gambo Muba fabrics made of silk, viscose, and rayon cotton. Various products in the garment industry that use Gambo Muba fabrics are shirts, blouses, dresses, and bomber jackets.

Gambier products compete with products that use textile dyes. The price of environmentally friendly gambier products tends to be more expensive than textile dye products (especially textile dye tiedye products). Gambier product differentiation occurs due to market demand for environmentally friendly products using natural dyes. This condition aligns with the opinion [33] that companies must expand consumer segmentation and develop unique environmentally friendly products to meet these consumer demands.

Table 3. Vertical Integration in Gambier Agro-industry

\begin{tabular}{|c|c|c|c|}
\hline Industry & Total Transaction Cost (IDR) & Value Added (IDR) & Price-Cost Margin (\%) \\
\hline \multicolumn{4}{|c|}{ Gambier Sap } \\
\hline Minimum & 52,000 & $2,297,500$ & 7.04 \\
\hline Maximum & 215,000 & $2,964,667$ & 36.26 \\
\hline Total & $1,312,000$ & $34,869,670$ & \\
\hline Average & 100,923 & $2,682,282$ & 21.90 \\
\hline \multicolumn{4}{|c|}{ Gambo Muba Fabric } \\
\hline Minimum & 81,000 & $16,617,500$ & 53.63 \\
\hline Maximum & 266,000 & $33,034,834$ & 64.70 \\
\hline Total & $283,117,703$ & $1,851,000$ & - \\
\hline Average & 142,385 & $21,778,285$ & 59.20 \\
\hline \multicolumn{4}{|c|}{ Garments } \\
\hline Minimum & 200,000 & $13,921,667$ & 22.46 \\
\hline Maximum & 398,000 & $31,281,537$ & 40.85 \\
\hline Total & $243,101,293$ & $3,788,500$ & - \\
\hline Average & 291,423 & $18,700,099$ & 32.70 \\
\hline \multicolumn{4}{|c|}{ Gambier Agro-industry (Agriculture Gambier until Garment Industry) } \\
\hline Minimum & 52,000 & $2,297,500$ & 7.04 \\
\hline Maximum & 398,000 & $33,034,834$ & 64.70 \\
\hline Total & $561,088,666$ & $6,951,500$ & - \\
\hline Average & 178,244 & $14,386,889$ & 38.04 \\
\hline
\end{tabular}

Source: Proceed Data, 2021 


\author{
(online) $=$ ISSN $2285-3642$ \\ ISSN-L = 2285-3642 \\ Journal of Economic Development, Environment and People \\ Volume 10, Issue 4, 2021 \\ URL: http://jedep.spiruharet.ro \\ e-mail: office jedep@spiruharet.ro
}

Transaction costs on agro-gambier low because these industries to integrate vertically related upstream and downstream supply chain. Cost components such as supplier coordination costs, distributor costs, and inter-company lobbying costs are lost because the companies are integrated and interconnected. The results of this study are in line with research conducted by [34] [25] and [35] which state that the impact of vertical integration can reduce transaction costs. In addition to lowering transaction costs, vertically integrated companies can ensure stable inputs and company sustainability [30].

In line with this, [27] analyzes vertical integration related to the value-added process of agricultural products in general, especially at various supply chain levels, and provides benefits to reduce environmental pollution and business sustainability in the agro-industry. Gambier has a high added value as a raw material for the fabric and clothing industry. Added value is the added value of a commodity because it undergoes processing, storage, and transportation in the production process [36] [37] [38]. Value-added is the total additional cost due to the addition of a chain of economic activities or stages of production. This value-added component includes factor income components (wages, interest, rent, and profits) and depreciation. In the agro-industry, there is a change from agricultural products to the processing industry. In addition to increasing the length of the chain of economic activities or production stages, it also increases the costs required for processing [39]. One of the goals of agro-industry is to produce added value from agricultural raw materials in the production process.

This result is also related to [40] alternative raw materials being the primary solution to develop agro products in India. In addition, [41] found that the use of alternative raw materials that are environmentally friendly, especially liquid waste, will improve the performance of the agricultural sector. A broader analysis carried out by [42] was related to the development of alternative raw materials creating forward and backward linkages to agro-industry. Price - Cost Margin (PCM) is an indicator of the company's ability to increase prices above production costs [43]. In the gambier agro-industry, the highest profit level is found in the Gambo Muba fabric industry; this is because the cost component in the Gambo Muba fabric industry is lower than other industries. In addition, the output value of the Gambo Muba fabric industry is higher than that of the garment industry.

\title{
5. Conclusion
}

Vertical integration reduces transaction costs, especially supplier coordination costs, distributor costs, and inter-company lobbying costs are lost due to the impact of vertically integrated companies. Vertical integration in the gambier agro-industry provides the benefits of high added value, environmental pollution reduction, and agro-industry sustainability. The impact of vertical integration gives companies the ability to increase prices above production costs so that the level of profit in the gambier agro-industry is high.

\section{References}

[1] A. Kumar, "Environmental Pollution by Textile Industries," pp. 20-26, Jun. 2016.

[2] T. Toprak and P. Anis, "Textile Industry's Environment Effect and Approaching Cleaner Production and Sustainability, an Overview," J. Text. Eng. Fash. Technol., vol. 2, no. 4, pp. 429-442, 2017. 


\author{
(online) $=$ ISSN $2285-3642$ \\ ISSN-L = $2285-3642$ \\ Journal of Economic Development, Environment and People \\ Volume 10, Issue 4, 2021 \\ URL: $\underline{\text { http://jedep.spiruharet.ro }}$ \\ e-mail: office jedep@spiruharet.ro
}

[3] M. R. Islam and M. G. Mostafa, "Textile Dyeing Effluents and Environment Concerns - A Review," J. Environ. Sci. Nat. Resour., vol. 11, pp. 131-144, 2018.

[4] V. Jaganathan, P. Cherurveettil, A. Chellasamy, and Premapriya, "Environmental Pollution Risk Analysis and Management in Textile Industry: A Preventive Mechanism," Eur. Sci. J., vol. 7881, no. August, pp. 480-486, 2014.

[5] D. Paraschiv, C. Tudor, and R. Petrariu, "The Textile Industry and Sustainable Development: A HoltWinters Forecasting Investigation for the Eastern European Area," Sustainability, vol. 7, pp. 12801291, 2015, doi: 10.3390/su7021280.

[6] S. Mukherjee, "Environmental and Social Impact of Fashiohowards an Eco -friendly, Ethical Fashion," Int. J. Interdiscip. Multidiscip. Stud., vol. 2, no. 3, pp. 22-35, 2015, [Online]. Available: http://www.ijims.com.

[7] U. S. P. R. Arachchige, K. D. Vithanage, R. T. Wadanambi, L. S. Wandana, W. M. M. P. Wijerathne, and N. R. G. S. S. Wimalarathne, "Environmental Impacts of Textile Industry In Sri Lanka," Int. J. Sci. Technol. Res., vol. 8, no. 09, pp. 251-253, 2019.

[8] F. Parvin, S. Islam, Z. Urmy, S. Ahmed, and A. S. Islam, "A Study on the Solutions of Environment Pollutions and Worker's Health Problems Caused by Textile Manufacturing Operations," J. Sci. Tech. Res., vol. 28, no. 4, pp. 21831-21844, 2020.

[9] F. Akarslan and H. Demiralay, "Effects of Textile Materials Harmful to Human Health," in International Conference on Computational and Experimental Science and Engineering (ICCESEN), 2015, vol. 128, pp. 407-408, doi: 10.12693/APhysPolA.128.B-407.

[10] A. M. Alanezi, "Impact of Pollution Generated by The Textile Industry on Health and Environment," J. Univ. Stud. Incl. Res., vol. 2, no. 3, pp. 160-176, 2018.

[11] N. Šajn, "Environmental Impact of The Textile and Clothing Industry: What Consumers Need to Know," Eur. Parliam. Res. Serv., no. January, 2019, [Online]. Available: https://www.europarl.europa.eu/RegData/etudes/BRIE/2019/633143/EPRS_BRI(2019)633143_EN.p df.

[12] S. Jordeva, M. Kertakova, S. Zhezhova, S. Golomeova-Longurova, and K. Mojsov, "Dyeing of Textiles with Natural Dyes," Tekst. Ind., vol. 68, no. 4, pp. 12-21, 2020, doi: 10.5937/tekstind2004012j.

[13] B. Ütebay, "Textile Wastes: Status and Perspectives," in Waste in Textile and Leather Sectors, P. Çelik, Ed. Rijeka: IntechOpen, 2020, p. Ch. 3.

[14] S. Failisnur, "Reuse of Liquid Waste from Textile Dyeing with Natural Dyes Gambier (Uncaria Gambir Roxb.) for Cotton Yarn Dyeing," ARPN J. Eng. Appl. Sci., vol. 12, pp. 5313-5318, Sep. 2017.

[15] P. C. Andreou, C. Louca, and P. M. Panayides, "The Impact of Vertical Integration on Inventory Turnover and Operating Performance," Int. J. Logist. Res. Appl., vol. 19, no. 3, pp. 218-238, May 2016, doi: 10.1080/13675567.2015.1070815.

[16] D. Zhang, "The Revival of Vertical Integration: Strategic Choice and Performance Influences," J. Manag. Strateg., vol. 4, no. 1, pp. 1-14, 2013.

[17] R. B. Grant, Contemporary Strategy Analysis, 8th ed. Great Britain: Wiley, 2016.

[18] Y. Prasertwattanakul and P. Ongkunaruk, "The Analysis of a Vertically Integrated Organic Rice Company : a Case Study in Thailand," Int. Food Res. J., vol. 25, no. April, pp. 481-486, 2018.

[19] R. F. Nadia and D. Cerquera, "The Role of Vertical Integration in Input Procurement," Bus. Manag. Stud. J., vol. 5, no. 1, pp. 26-35, 2017.

[20] A. Grau and A. Reig, "The Industry Effect and The Decision to Integrate Vertically in a Crisis Context," 


\author{
(online) = ISSN $2285-3642$ \\ ISSN-L = $2285-3642$ \\ Journal of Economic Development, Environment and People \\ Volume 10, Issue 4, 2021 \\ URL: http://jedep.spiruharet.ro \\ e-mail: office jedep@spiruharet.ro
}

Eur. J. Financ., vol. 25, no. 16, pp. 1591-1605, Nov. 2019, doi: 10.1080/1351847X.2019.1628795.

[21] Y. S. Tey and P. Arsil, "Vertical and Horizontal Integration in the Profitability of Malaysian Boiler Firms," Trop. Anim. Sci. J., vol. 44, no. 1, 2021, doi: http://doi.org/10.5398/tasj.2021.44.1.115.

[22] F. Carillo, F. Caracciolo, and L. Cembalo, "Vertical Integration in Agribusiness . Is it a Bargain?," in PROCEEDINGS OF THE 52ND SIDEA CONFERENCE, 2016, no. October, doi: 10.13128/REA-18624.

[23] M. Hamdaoui and B. Bouayad, "Determinants and Effects of Vertical Integration on the Performance of Moroccan Manufacturing," Athens J. Mediterr. Stud., vol. 5, no. 1, pp. 57-78, 2019.

[24] A. M. Benmehaia and F. Brabez, "The Empirical Factors Determining Vertical Integration in Algerian Food Manufacturing Sector," Eur. Sci. Journal, ESJ, vol. 12, no. 28, pp. 252-262, 2016.

[25] M. Deng and A. Zhang, "Effect of Transaction Rules on Enterprise Transaction Costs Based on Williamson Transaction Cost Theory in Nanhai , China," Sustainability, vol. 12, 2020, doi: doi:10.3390/su12031129.

[26] A. P. Fernandes and H. Tang, "Determinants of Vertical Integration in Export Processing: Theory and Evidence from China," J. Dev. Econ., vol. 99, no. 2, pp. 396-414, 2012, doi: http://dx.doi.org/10.1016/j.jdeveco.2012.05.004.

[27] R. Priyadarshi and S. Routroy, "Vertical Integration Level Selection for Value Addition of Herbal Products: A Farmer's Perspective," in Materials Today: Proceedings, 2018, vol. 5, no. 9, pp. 1835418361, doi: 10.1016/j.matpr.2018.06.174.

[28] P. M. Ralston, J. Blackhurst, D. E. Cantor, and M. C. Crum, "A Structure - Conduct - Performance Perspective of How Strategic Supply Chain Integration Affects Firm Performance," J. Supply Chain Manag., vol. 50, no. 2, 2015, doi: 10.1111/jscm.12064.

[29] K. R. Harrigan, “A Framework for Looking at Verical Integration," J. Bus. Strategy, 2001.

[30] D. W. Carlton and J. M. Perloff, Modern Industrial Organization, Second Edi. New York: Harper Collins College Publishers, 1994.

[31] Z. Zulfiandri, M. S. Maarif, A. Hermawan, and H. H. Hardjomidjojo, "Biaya Transaksi dan Benefit Cost pada Integrasi Vertikal Rantai Nilai Agroindustri Kakao Skala Kecil Biaya Transaksi Dan Benefit Cost pada Integrasi Vertikal Rantai Nilai Agroindustri Kakao Skala Kecil," J. Manaj. Agribisnis, vol. 14, no. 3, pp. 187-197, 2017, doi: 10.17358/jma.14.3.187.

[32] C. R. Kothari, Research: Methodology Methods and Techniques, 3rd ed. India: New Age International Publishers, 2013.

[33] D. He and X. Deng, "Price Competition and Product Differentiation Based on the Subjective and Social Effect of Consumers ' Environmental Awareness," Int. J. Environ. Res. adn Public Heal., vol. 17, pp. 9-12, 2020, doi: 10.3390/ijerph17030716.

[34] T. Todorova, "Vertical Integration in High-Transaction Cost Sectors: The Case of the Bulgarian Pharmaceutical Industry," J. Adv. Res. Manag., vol. 1, no. 2, pp. 127-138, 2010.

[35] L. Klüppel, The Role of Transaction Costs on Vertical Integration and Innovation: A General Equilibrium Approach. 2021.

[36] M. Hamidah, A. H. Yusra, and J. Sudrajat, "Analisis Nilai Tambah Agroindustri Kripik Ubi di Kota Pontianak," J. Soc. Econ. Agric., vol. 4, no. 1987, pp. 60-73, 2015.

[37] S. Hadi, M. I. Wahyudi, M. Hazmi, and H. Prayuginingsih, "Assessment of Value Added and Development Opportunity of Agroindustry Activity based on Marine Resources in Sub District of Panarukan, District of Situbondo," in E3S Web of Conferences 52 (CSSPO), 2018, vol. 00046, pp. 1-9, doi: https://doi.org/10.1051/e3sconf/20185200046. 


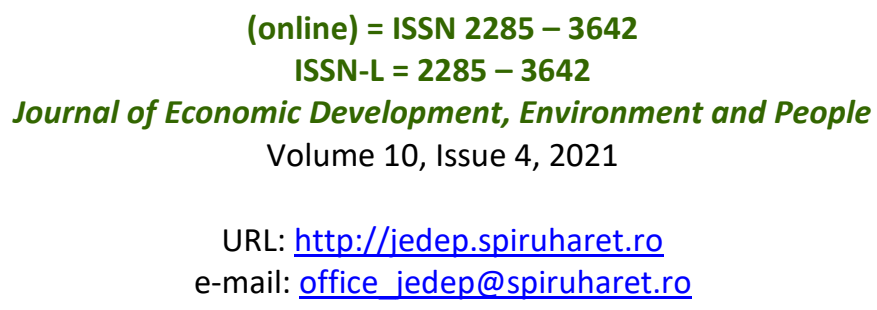

[38] M. Asrol, Marimin, Machfud, M. Yani, and E. Taira, "Supply Chain Fair Profit Allocation Based on Risk and Value Added for Sugarcane Agro-industry," Oper. Supply Chain Manag., vol. 13, no. 2, pp. 150165, 2020.

[39] P. Samuelson, Economics. Mac Grawhill Publishing Co. Tokyo, 1980.

[40] Sanal and K. S. Kumar, "An Analysis of Value Addition in Agro Products and Its Impact on the Export Potentials of India," Int. J. Manag., vol. 8, no. 4, pp. 23-30, 2017.

[41] L. Priscilla, A. Balakrishnan, and A. K. Chauhan, "A Study on the Performance of Agricultural Sector in India," Indian J. Agric. Reserach, vol. 51, no. 3, pp. 282-286, 2017.

[42] J. L. Figueroa, M. Mahmoud, and C. Breisinger, "The Role of Agriculture and Agro-Processing for Development in Jordan," 2018. doi: 10.2499/1024320700.

[43] J. Lipczynski, J. Wilson, and J. Goddard, Industrial Organization: Competition, Strategy, Policy, 2nd ed. England: Prentice-Hall, 2005. 